ОРГАНІЗАЦІЙНО-ПРАВОВИЙ МЕХАНІЗМ ПУБЛІЧНОГО АДМІНІСТРУВАННЯ РОЗВИТКУ ДЕМОКРАТИЧНОГО ТРАНЗИТУ (НА ПРИКЛАДІ ПРАВООХОРОННОЇ ДІЯЛЬНОСТІ)

\title{
ORGANIZATIONAL AND LEGAL MECHANISM OF PUBLIC ADMINISTRATION OF DEVELOPMENT OF DEMOCRATIC TRANSIT (ON THE EXAMPLE OF LAW ENFORCEMENT ACTIVITY)
}

Показано, що демократичні перетворення асоціюються з новим перспективним напрямом розвитку української держави, реалізачія яких забезпечить розвиток суспільства, держави відповідно до сьогоденних потреб. Обгрунтовано, що на особливу увагу під час демократичних перетворень заслуговує реформа правоохоронної діяльності, оскільки в ї основі - політичний інтерес, метою якого є створення умов для забезпечення правопорядку у країні, а також безпечних умов життя. Показано прочес ресрормування правоохоронної сорери, а також проаналізовано зміни в законодавстві України, що призвели до збільшення злочинності та зростання корупції.

Проаналізовано судову ресрорму, що суттєво змінила фуункиіі органів прокуратури, але протягом наступних двох років так не узгодили з ними ні норми Закону «Про прокуратуру», ні Кримінальний прочесуальний кодекс Украӥни; коли після ухвалення 1 січня 2017 року Закону, яким було вилучено цілий розділ Податкового кодексу України, що визначав правові засади існування податкової поліції, зробили поза законом діяльність Державного бюро розслідувань, яке продовжує і дотепер здійснювати як оперативно-розшукову діяльність, так і досудове розслідування. Показано, що протягом п'яти років, передбачених Законом, так і не запустили в дію те ж Державне бюро розслідувань, через що слідчі прокуратури із 20 листопада 2017 року втратили свої повноваження у сорері проведення досудового розслідування підслідних йому злочинів. Як результат, більше року в чій ссрері панував хаос; установлено, що на початку діяльно сті того ж Державного бюро розслідувань у листопаді 2018 року не було своєчасно внесено необхідних змін до Кримінального процесуального кодексу про можливість і надалі застосовувати процедуру спеціального розслідування та заочного засудження до підозрюваних осіб, які переховуються від органів слідства та суду на окупованих територіях тощо.

Обгрунтовано, що внаслідок такої хаотичної законодавчої діяльності суттєво послаблено кількість і особливо якість кадрового стану органів прокуратури і Нацполіції унаслідок непродуманого звільнення працівників насамперед - досвідчених) через так звану «люстрацію» та під виглядом «очищення» від «старих» кадрів, які, начебто, усі, без винятку, скомпроментовані й корумповані, через невмотивовані «атестації» та «переатестації», так звані «конкурси», де такі рішення здебльшого ухвалювали некомпетентні, випадкові люди, чого, до речі, немає в жодній країні Європи. Показано, що напрацьований досвід розкриття й розслідування злочинів поспішно відкинутий i позабутий, нинішня організація роботи кожного з відомств, де майже всі керівники чентрального апарату (та й на регіональ- ному рівні також) не мають необхідного досвіду роботи на адміністративних посадах в органах прокуратури, ніколи не працювали слідчими і не знають взагалі, що таке прокурорський нагляд, а у формі процесуального керівництва і поготів, перебуває на вкрай низькому рівні.

Ключові слова: організаційно-правовий механізм, демократичний транзит, ресрорми, правоохоронна діяльність, публічне адміністрування.

It is shown that democratic transformations are associated with a new promising direction of development of the Ukrainian state, the implementation of which will ensure the development of society, the state in accordance with today's needs. It is substantiated that the reform of law enforcement activity deserves special attention during democratic transformations, as it is based on political interest, the purpose of which is to create conditions for ensuring law and order in the country, as well as safe living conditions. The process of reforming the law enforcement sphere is shown, as well as the changes in the legislation of Ukraine that have led to an increase in crime and the growth of corruption are analyzed.

Judicial reform was analyzed, which significantly changed the functions of the prosecutor's office, but over the next two years neither the provisions of the Law on the Prosecutor's Office nor the CPC of Ukraine were brought into line with them; when after the adoption on January 1, 2017 of the law, which excluded the entire section of the Tax Code of Ukraine, which defined the legal basis for the existence of the tax police, outlawed the State Bureau of Investigation, which continues to carry out both operational and pre-trial activities investigation. It is shown that within the five years provided by law, the same State Bureau of Investigation was not launched, as a result of which, on November 20,2017, investigators of the prosecutor's office lost their authority to conduct a pre-trial investigation of crimes under investigation. As a result, complete chaos reigned in this area for more than a year; It was established that at the beginning of the activity of the same State Bureau of Investigation in November 2018 the necessary amendments to the Criminal Procedure Code on the possibility to continue and further apply the procedure of special investigation and absentee conviction to suspects hiding from the investigation and court occupied territories, etc.

It is substantiated that as a result of such chaotic legislative activity both the number and, in particular, the quality of the staff of the prosecutor's office and the National Police are significantly weakened - as a result of ill-considered dismissal of employees (primarily experienced) due to so-called "lustration" "From the" old "cadres, who seem to be all, without exception, compromised and corrupt, due to unmotivated "certifications" and "re-certifications", and even more so because of the so-called "competitions", where such decisions, in the vast majority, were та кримінально-правових дисциплін

Університет митної справи та фрінансів 
made by incompetent, random people, which, incidentally, is not in any European country. It is shown that the experience gained in detecting and investigating crimes is hastily rejected and forgotten, the current organization of each department, where almost all heads of the cen tral office (and at the regional level as well) do not have the necessary experience in adminis- trative positions in the prosecutor's office, never worked investigators do not know at all what prosecutorial supervision is, and even more so in the form of procedural guidance, is at an extremely low level.

Key words: organizational and legal mechanism, democratic transit, reforms, law enforcement, public administration.
Постановка проблеми в загальному вигляді. Уряд України намагається досягти європейських стандартів життя в найкоротші строки, здійснює реформування всіх сфер життєдіяльності суспільства, зокрема й охорони здоров'я, пенсійної, правоохоронної, судової, освіти тощо. Реалізація реформ на практиці стикається з багатьма правовими, організаційними, економічними проблемами, іноді може мати гірший ефект, ніж було, що сталося на прикладі правоохоронної діяльності. Дана ситуація актуалізує потребу аналізу організаційно-правового забезпечення реалізації реформи правоохоронної діяльності за умов демократичного транзиту.

Аналіз останніх досліджень і публікацій. Розвиток транзитивного простору здійснюється у складних умовах, що пов'язано з розвитком технологій та науки, а також висуває перед суспільством нові завдання, що мають бути враховані під час проведення реформ, та зумовлює потребу створення належного науково-теоретичного підґрунтя. Транзитивні процеси досліджували М. Бойко (туристична галузь) [2, с. 53], Н. Ведмідь (туристична галузь) [2, с. 53], А. Охріменко (туристична галузь) [2, с. 53], В. Березинський (виборча система), О. Бабкіна (транзитивне суспільство) $[1$, с. 5] тощо. Юридичний аспект розвитку транзитивного простору досліджувала Л. Матвєєва. Питання, пов'язані із правоохоронною діяльністю та правовим статусом правоохоронних органів, розробляли О. Бандурка, В. Безчасний, В. Білоус, В. Галунько, Ю. Загуменна, Р. Калюжний, В. Колпаков, А. Комзюк, А. Кучук, О. Мартиненко, М. Мельник, Т. Пікуля, В. Плішкін, В. Серьогін, В. Тацій, П. Хамула, Ю. Шемшученко. Проте, незважаючи на велику кількість наукових розвідок, присвячених розвитку транзитивного простору України, недослідженими залишаються питання розвитку демократичного транзиту у сфері правоохоронної діяльності.

Мета статті - зробити аналіз організаційно-правового механізму розвитку демократичного транзиту на прикладі правоохоронної діяльності, обґрунтувати напрями для його розвитку.

Виділення не вирішених раніше частин загальної проблеми. Наукова актуальність дослідження зумовлена перехідними процесами, що відбуваються в Україні, та особливостями нашої держави, що зумовлено українською культурою, традиціями, радянськими минулим, сусідством із пострадянськими та європейськими країнами, що визначає особливість транзитивних процесів, які відбуваються в нашій державі. Науковці приділяють увагу проблемам розвитку демократичного транзиту, але внаслідок проведення реформ у сфері правоохоронної діяльності ситуація постійно змінюється, спричиняє появу непередбачуваних проблемних випадків, що потребують негайного аналізу й обґрунтування заходів для вдосконалення розвитку даної сфери.

Виклад основного матеріалу. Для всіх пострадянських країн характерний процес перебудови, що має на меті заснування демократії в найкоротший час. Цей тимчасовий процес характерний і для нашої держави, що пов'язано з намаганням українського уряду та парламенту запровадити ефективні реформи, що забезпечили б у короткочасній перспективі досягнення європейських стандартів життя. Демократичні перетворення асоціюються 3 новим перспективним напрямом поступу держави, що забезпечить розвиток суспільства, держави відповідно до сьогоденних потреб.

В Україні впроваджуються різноманітні реформи, зокрема у сферах охорони здоров'я, пенсійній, правоохоронній, судовій, освіти тощо. Цей етап називають етапом демократичного транзиту, оскільки наша держава намагається досягти європейських стандартів життя у найкоротші строки, упроваджує реформи в пошуках побудови оптимальної моделі держави відповідно до європейських стандартів.

На особливу увагу заслуговує реформа правоохоронної діяльності, оскільки в ії основі - політичний інтерес, мета якого - створення умов для забезпечення правопорядку у країні, а також безпечних умов життя.

Метою проведення реформи правоохоронних органів є створення ефективної системи досудового розслідування кримінальних правопорушень, формування незалежних реформованих органів прокуратури, створення дієвого органу розслідування злочинів, учиненх працівниками органів правопорядку, - 
Державного бюро розслідувань, удосконалення законодавство про поліцейську діяльність, яке відповідає Конституції України та європейським стандартам, формування прогресивної й ефективної системи розслідування економічних злочинів, а також дієвої системи громадського контролю за діяльністю органів правопорядку.

У результаті проведеного аналізу всіх змін протягом останніх чотирьох років у сфері правоохоронної діяльності, які вносилися до законодавства України, щодо боротьби зі злочинністю та корупцією, можна дійти зовсім невтішного висновку про те, що як такої «реформи» у цій сфері не відбулося. Навпаки, без попереднього прогнозування й аналізу, без широкого обговорення в суспільстві, без залучення найкращих вітчизняних авторитетних науковців і практиків нав'язані нам ззовні так звані «реформи», насамперед під виглядом узгодження українських правоохоронних органів із «європейськими стандартами», не принесли очікуваного результату. Як наслідок, правоохоронна система України натепер цілком зруйнована, а ці органи (як старі, так і нові) перетворилися на структури, які існують самі собою, а в частині виконання покладених функцій держави із захисту конституційних прав і свобод громадян, забезпечення дотримання принципу верховенства права й інших засад кримінального провадження - панує безлад.

Спочатку під час ухвалення Закону України «Про національну поліцію» на цілий рік позбавили нову поліцію права здійснювати оперативно-розшуковудіяльність; тежсаме «забули» передбачити і в Законі «Про Державне бюро розслідувань», уже понад рік усіляко ухиляються від унесення до нього необхідних змін. у зв'язку із проведенням судової реформи суттєво змінили функції органів прокуратури, але протягом наступних двох років так і не узгодили з ними ні норми Закону «Про прокуратуру», ні Кримінальний процесуальний кодекс України; коли після ухвалення 1 січня 2017 р. Закону, яким було вилучено цілий розділ Податкового кодексу України, що визначав правові засади існування податкової поліції, зробили поза законом діяльність Державного бюро розслідувань, яке продовжує і дотепер здійснювати як оперативно-розшукову діяльність, так і досудове розслідування. Протягом п'яти років, передбачених Законом, так і не запустили в дію те ж Державне бюро розслідувань, унаслідок чого слідчі прокуратури із 20 листопада 2017 р. втратили свої повноваження у сфері проведення досудового розслідування підслідних йому злочинів. Як результат, більше року в цій сфері панував хаос; коли після початку діяльності того ж Державного бюро розслідувань у листопаді 2018 р. не було своєчасно внесено необхідних змін до Кримінального процесуального кодексу про можливість і надалі застосовувати процедуру спеціального розслідування та заочного засудження до підозрюваних осіб, які переховуються від органів слідства та суду на окупованих територіях тощо [3].

У результаті такої хаотичної законодавчої діяльності суттєво послаблено кількість і особливо якість кадрового стану органів прокуратури і Нацполіції - унаслідок непродуманого звільнення працівників (передусім - досвідчених) через так звану «люстрацію» та під виглядом «очищення» від «старих» кадрів, які, начебто, усі, без винятку, скомпроментовані й корумповані, через невмотивовані «атестації» та «переатестації», так звані «конкурси», де такі рішення здебільшог ухвалювали некомпетентні, випадкові люди, чого, до речі, немає в жодній країні Європи. А як результат напрацьований досвід розкриття й розслідування злочинів поспішно відкинутий і позабутий, нинішня організація роботи кожного 3 відомств, особливо Генеральної прокуратури України, де майже всі керівники центрального апарату (та й на регіональному рівні також) не мають необхідного досвіду роботи на адміністративних посадах в органах прокуратури, ніколи не працювали слідчими і не знають взагалі, що таке прокурорський нагляд, а у формі процесуального керівництва і поготів, перебуває на вкрай низькому рівні [3].

Не в останню чергу негативно позначилася на якості й ефективності боротьби зі злочинністю і корупцією поспішна ліквідація підрозділів прокурорів-криміналістів та спецпідрозділів із боротьби з організованою злочинністю, державної автомобільної інспекції та патрульно-постової служби.

У червні 2016 р. внесли зміни до Конституції України у зв'язку з ухваленням так званої «судової реформи», якими прокуратуру також було позбавлено конституційної функції нагляду за додержанням законів органами, які проводять оперативно-розшукову діяльність і досудове слідство, зокрема й дотримання ними вимог галузевих законів, залишивши за прокурором, згідно з вимогами ст. 25, лише права й виконання обов'язків, передбачених Законом «Про оперативно-розшукову діяльність» та Кримінальним процесуальним кодексом України, унаслідок чого правоохоронні органи, які повинні боротися зі злочинністю, залишилися безконтрольними та безнаглядними, а прокурор був позбавлений можливості в межах правового поля реагувати як на пору- 
шення ними законів та прав і свобод громадян, так і на їхню бездіяльність.

Закон «Про прокуратуру» мав би усунути дублювання та чітко розмежувати функції правоохоронних огранів, налагодити ефективний контроль за їхньою діяльністю, нарешті, забезпечити законність і правопорядок у державі [5].

Варто сказати, що після ухвалення неконституційного Закону «Про прокуратуру» прокурори також були позбавлені прав і повноважень проводити в усіх органах досудового розслідування й оперативних підрозділах перевірки на предмет дотримання ними законів із боротьби зі злочинністю і навіть додержання вимог Кримінального процесуального кодексу на досудовому розслідуванні, а вносити за результатами таких перевірок їхнім керівникам документи прокурорського реагування і поготів, причому без різниці, як їх можна назвати: чи це письмові вимоги, чи приписи, чи подання з вимогами усунення виявлених порушень законів та притягнення винних правоохоронців, зокрема і їхніх керівників, до відповідальності, а порушувати дисциплінарні провадження і поготів [4].

Отже, реформа правоохоронних органів була провальною через хаотичність та непродуманість ухвалення законодавчих актів, унаслідок чого буди втрачені високопрофесійні кадри.

Висновки. Отже, на політичному рівні у Верховній Раді України не було чіткого плану дій щодо внесення змін до законодавства України та не було визначено відповідального органу за здійснення реформ. Непродуманість державної політики розвитку правоохоронних органів за умов демократичного транзиту призвела до відтоку спеціалістів та появи малодосвідчених людей. Уникнення таких колізій потребує визначення конкретного органу для контролю за проведенням реформ, розроблення дорожньої карти.

Перспективою подальших наукових досліджень є розгляд економічного механізму розвитку демократичного транзиту.

\section{ЛITЕРАТУРА:}

1. Бабкіна О. Передумови переходу до демократії: ризики транзитивного суспільства. Науковий часопис Національного педагогічного університету імені М.П. Драгоманова. 2015. № 17. С. 3-11.

2. Бойко М., Ведмідь Н., Охріменко А. Транзитивність національної туристичної системи. Зовнішня торгівля: економіка, фрінанси, право. 2018. № 5. C. 55-66.

3. Провальні реформи. Сучасний стан правоохоронної діяльності щодо боротьби зі злочинністю та корупцією в Україні (окремий аналіз за кожним відомCTBOM). URL: https://lexinform.com.ua/dumka-eksperta/ provalni-reformy-suchasnyj-stan-pravoohoronnoyidiyalnosti-shhodo-borotby-zi-zlochynnistyu / (дата звернення: 20.05.2021)

4. Щодо відновлення ефективної діяльності прокуратури та органів досудового розслідування. URL: https://lexinform.com.ua/dumka-eksperta/shhodovidnovlennya-efektyvnoyi-diyalnosti-prokuratury-taorganiv-dosudovogo-rozsliduvannya/ (дата звернення: 20.05.2021).

5. Реформа правоохранительных органов - путь к феодализму и коллективной безответственности. URL: https://www.pravda.com.ua/ rus/columns/2018/05/11/7179981/ (дата звернення: 15.05.2021). 